Maria Fernanda Figueiredo de Oliveira

\title{
Conventional and simplified-hybrid boundary element methods applied to axisymmetric elasticity problems in fullspace and halfspace
}

\section{TESE DE DOUTORADO}

DEPARTAMENTO DE ENGENHARIA CIVIL

Postgraduate Program in Civil Engineering 


\section{Maria Fernanda Figueiredo de Oliveira}

\section{Conventional and simplified-hybrid boundary element methods applied to axisymmetric elasticity problems in fullspace and halfspace}

Tese de Doutorado

Thesis presented to the Postgraduate Program in Civil Engineering of the Departamento de Engenharia Civil, PUC-Rio as partial fulfillment of the requirements for the degree of Doutor em Engenharia Civil

Advisor: Prof. Ney Augusto Dumont Co-Advisor: Prof. Antony Patrick Sinnappa Selvadurai 


\title{
Pontifícia Universidade Católica $_{\text {a }}$

Maria Fernanda Figueiredo de Oliveira

\begin{abstract}
Conventional and simplified-hybrid boundary element methods applied to axisymmetric elasticity problems in fullspace and halfspace
\end{abstract}

Thesis presented to the Postgraduate Program in Civil Engineering, of the Departamento de Engenharia Civil do Centro Técnico Científico da PUC-Rio, as partial fulfillment of the requirements for the degree of Doutor.

Prof. Ney Augusto Dumont

Advisor

Departamento de Engenharia Civil - Puc-Rio

Prof. Antony Patrick Sinnappa Selvadurai

Co-Advisor

Department of Civil Eng. and Applied Mechanics - McGill University

Prof. Euclides de Mesquita Neto

Departamento de Mecânica Computacional — UNICAMP

Prof. Jose Claudio de Faria Telles

Programa de Engenharia Civil — COPPE/UFRJ

Prof. Rubens de Oliveira Departamento de Ciência da Computação - UFJF

Prof. Celso Romanel

Departamento de Engenharia Civil — PUC-Rio

Prof. Raul Rosas e Silva

Departamento de Engenharia Civil — PUC-Rio

Prof. José Eugenio Leal

Coordinator of the Centro Técnico Científico - PUC-Rio

Rio de Janeiro, $13^{\text {th }}$ April 2009 
All rights reserved.

\section{Maria Fernanda Figueiredo de Oliveira}

Graduated in Civil Engineering from Universidade Federal do Paraná - UFPR in 2002, obtained the degree of Mestre in Civil Engineering from Pontifical Catholic University of Rio de Janeiro - PUC-Rio in 2004.

Bibliographic data

Oliveira, Maria Fernanda Figueiredo de

Conventional and simplified-hybrid boundary element methods applied to axisymmetric elasticity problems in fullspace and halfspace/ Maria Fernanda Figueiredo de Oliveira; advisor: Ney Augusto Dumont; co-advisor: Antony Patrick Sinnappa Selvadurai. - Rio de Janeiro : PUC-Rio, Departamento de Engenharia Civil , 2009.

v., 130 f: il. ; $29,7 \mathrm{~cm}$

1. Tese (doutorado) - Pontifícia Universidade Católica do Rio de Janeiro, Departamento de Engenharia Civil .

Inclui referências bibliográficas.

1. Engenharia Civil - Tese. 2. Método dos elementos de contorno. 3. Método híbrido simplificado dos elementos de contorno. 4. Axissimetria. 5. Semi-espaço.

I. Dumont, Ney Augusto. II. Selvadurai, Antony Patrick Sinappa. III. Pontifícia Universidade Católica do Rio de Janeiro. Departamento de Engenharia Civil . IV. Título. 


\section{Acknowledgements}

I wish to express sincere gratitude to my supervisor, Prof. N. A. Dumont, for his continuous guidance and close support during the entire duration of this study in the Postgraduate Program of Civil Engineering at the Pontifical Catholic University of Rio de Janeiro (PUC-Rio).

Prof. A. P. S. Selvadurai is also gratefully thanked for his expert advice and encouragement during my valuable experience as a student visitor of the Department of Civil Engineering and Applied Mechanics at the McGill University.

Also, I am grateful to the Professors and staff of the Civil Engineering Department at the Pontifical Catholic University of Rio de Janeiro (PUC-Rio) for creating a friendly and stimulating environment.

I would like to acknowledge the Brazilian agencies National Council for Scientific and Technological Development (CNPq) and Capes Foundation (CAPES), and the Computer Graphics Technology Group (TecGraf) at the Pontifical Catholic University of Rio de Janeiro (PUC-Rio), for their financial support.

I specially thank all friends for enjoying a cup of coffee in the afternoons and sharing the everyday life.

Above all, I am indebted to my parents and brothers, for their love and support. This thesis is dedicated to them. 


\section{Abstract}

Oliveira, Maria Fernanda Figueiredo de; Dumont, Ney Augusto; Selvadurai, Antony Patrick Sinappa. Conventional and simplified-hybrid boundary element methods applied to axisymmetric elasticity problems in fullspace and halfspace. Rio de Janeiro, 2009. 130p. Tese de Doutorado — Departamento de Engenharia Civil , Pontifícia Universidade Católica do Rio de Janeiro.

This thesis presents the formulation of the conventional and simplified-hybrid boundary element methods for axisymmetric problems, employing fullspace as well as halfspace fundamental solutions. As it is mostly found in the literature on axisymmetric problems in the elastic halfspace, the boundary element formulations make use of fullspace fundamental solutions and insert a mesh discretization of the free surface, with truncation at a reasonable distance from the axis of axisymmetry. This discretization can be circumvented if one employs the fundamental solutions that satisfy in advance the traction free boundary condition on the free surface. This work presents the implementation of these axisymmetric fundamental solutions for both the fullspace and the halfspace, given in terms of integrals of Lipschitz-Hankel type. Explicit equations for post-processing results at internal points are provided, as well as the adequate numerical schemes to evaluate the boundary integrals that arise in the formulation. It is shown that the boundary element method for the halfspace can be easily implemented from existing computation codes for fullspace problems, requiring only a few modifications. This work also addresses the simplified-hybrid boundary element method for the axisymmetric fullspace and halfspace problems. In its original version, the use of spectral properties to completely formulate the method was possible for only strictly non-convex topological configurations. The key contribution of the present developments consisted in the correct application of a hybrid contragradient theorem to derive a simple means of using analytical solutions of the elastic problem in order to substitute for the spectral properties that have been originally proposed. In the simplified-hybrid boundary element method, only one matrix requires integration and the results at internal points can be evaluated directly, which makes the method extremely advantageous for axisymmetric problems. Some numerical examples validate the proposed formulations.

\section{Keywords}

Boundary element method; Simplified-hybrid boundary element method; Axisymmetry; Halfspace. 


\section{Resumo}

Oliveira, Maria Fernanda Figueiredo de; Dumont, Ney Augusto; Selvadurai, Antony Patrick Sinappa. Métodos de elementos de contorno convencional e híbrido simplificado aplicados a problemas axissimétricos de elasticidade no espaço completo e no semi-espaço. Rio de Janeiro, 2009. 130p. Tese de Doutorado - Departamento de Engenharia Civil , Pontifícia Universidade Católica do Rio de Janeiro.

Este tese apresenta as formulações dos métodos de elementos de contorno convencional e híbrido simplificado para problemas axissimétricos de elasticidade, empregando-se as soluções fundamentais do espaço completo e do semi-espaço. Para problemas de elasticidade axissimétricos no semi-espaço pelos métodos de elementos de contorno, o uso das soluções fundamentais para espaço completo exige a discretização e o truncamento da superfície livre. No entanto, essa discretização é dispensada se as soluções fundamentais empregadas satisfizerem a condição de forças de superfície nulas. Este trabalho apresenta a implementação dessas soluções fundamentais axissimétricas para o espaço completo e o semiespaço elástico, em termos de integrais do tipo Lipschitz-Hankel. São apresentadas todas as expressões necessárias para o cálculo de resultados em pontos internos e a correta integração numérica das integrais de contorno. Partindo da formulação do espaço completo, mostra-se que é necessária pouca modificação para a implementação da formulação proposta. Esse trabalho também desenvolve a formulação axissimétrica para o método híbrido simplificado dos elementos de contorno, tanto para o espaço completo como para o semi-espaço. Na sua versão original, o uso de propriedades espectrais para a total formulação do problema não era possível para certas configurações topológicas. No entanto, a aplicação de um princípio de contragradiência híbrida às equações do método levou à obtenção de uma nova relação matricial que tornou possível sua total formulação para qualquer topologia, independentemente de propriedades espectrais. A necessidade de se integrar apenas uma matriz e a facilidade de obtenção de resultados em pontos internos tornam o método híbrido simplificado dos elementos de contorno ainda mais vantajoso para problemas axissimétricos. Alguns exemplos numéricos validam as formulações apresentadas. Essa tese é composta por oito capítulos e dois apêndices, como descritos a seguir. O Capítulo 2 trata das soluções fundamentais axissimétricas para o espaço completo e o semi-espaço elástico. As equações governantes para um meio elástico axissimétrico são apresentadas em coordenadas cilíndricas. As soluções fundamentais correspondentes são deduzidas, em termos de integrais do tipo LipschitzHankel, a partir da solução de Muki das equações de equilíbrio de Navier. O Capítulo 3 apresenta o método dos elementos de contorno para problemas axissimétricos 
no espaço completo e no semi-espaço. A partir das soluções fundamentais apresentadas no Capítulo 2, as equações integrais no contorno são deduzidas, bem como as equações matriciais governantes. Além disso, discute-se a obtenção de uma matriz de rigidez e o cálculo das inversas generalizadas presentes na formulação. As expressões para o cálculo de deslocamentos e tensões no domínio e ao longo do contorno são fornecidas de maneira explícita. O Capítulo 4 apresenta o método híbrido simplificado dos elementos de contorno para problemas axissimétricos no espaço completo e no semi-espaço. Uma nova versão do método é proposta, em que as equações governantes do problema são obtidas a partir de trabalhos virtuais de deslocamentos, uma equação de compatibilidade de deslocamentos e um teorema híbrido de contragradiência. O esquema para o cálculo dos coeficientes indeterminados de $\mathbf{U}^{*}$ está descrito detalhadamente para o espaço completo, incluindo as soluções analíticas necessárias. A obtenção de uma matriz de rigidez, bem como de deslocamentos e tensões em pontos internos, também é discutida. Bases ortonormais, projetores e inversas generalizadas presentes na formulação são apresentados ao longo do capítulo. O Capítulo 5 apresenta os esquemas numéricos para o cálculo das integrais presentes nos métodos de elementos de contorno convencional e híbrido simplificado aplicados a problemas axissimétricos no espaço completo e no semi-espaço. Os casos de integração estão agrupados segundo a posição do anel de carregamento da solução fundamental em relação ao eixo de axissimetria e ao segmento do contorno ao longo do qual a integral está sendo avaliada. O Capítulo 6 apresenta os exemplos numéricos para problemas axissimétricos finitos, infinitos e no semi-espaço resolvidos pelos métodos de elementos de contorno convencional e híbrido simplificado. Os resultados de deslocamentos e tensões são comparados com a solução analítica ao longo do contorno e em alguns pontos do domínio. O Capítulo 7 apresenta as conclusões de cada aspecto discutido neste trabalho, enfatizando as vantagens e as desvantagens dos métodos de elementos de contorno convencional e híbridos simplificado para problemas axissimétricos no espaço completo e no semi-espaço. Além disso, as contribuições desse trabalho são sumarizadas e algumas questões ainda não respondidas também são formuladas. Finalmente, o Apêndice A refere-se às integrais do tipo Lipschitz-Hankel com produtos de função de Bessel, fornecendo suas expressões explícitas em termos de integrais elípticas completas. O Apêndice B apresenta um resumo dos esquemas numéricos utilizados no cálculo das integrais regulares, integrais fracamente singulares com termos logarítmicos e parte finita de integrais singulares.

\section{Palavras-chave}

Método dos elementos de contorno; Método híbrido simplificado dos elementos de contorno; Axissimetria; Semi-espaço. 


\section{Contents}

1 Introduction $\quad \mathbf{1 4}$

1.1 The boundary element method for axisymmetric elasticity 15

1.2 The simplified-hybrid boundary element method for axisymmetric elasticity 16

$\begin{array}{lll}1.3 & \text { Volume composition } & 18\end{array}$

2 Fundamental solutions for an axisymmetric isotropic elastic medium $\quad \mathbf{2 0}$

2.1 Governing equations 21

2.2 Fundamental solution for the axisymmetric fullspace 23

2.3 Fundamental solution for the axisymmetric halfspace 27

2.4 Properties of the fundamental solution 29

3 The boundary element method for axisymmetric elasticity 30

3.1 Formulation for the axisymmetric fullspace problem 31

3.2 Formulation for the axisymmetric halfspace problem 42

4 The simplified-hybrid boundary element method for axisymmetric elasticity 446

4.1 Formulation for the axisymmetric fullspace problem 46

4.2 Formulation for the axisymmetric halfspace problem 69

5 Numerical integration $\quad 71$

5.1 Integrals for the axisymmetric fullspace problem 71

$\begin{array}{lll}5.2 & \text { Integrals for the axisymmetric halfspace problem } & 77\end{array}$

6 Numerical examples $\quad \mathbf{8 2}$

6.1 Examples for finite domains 83

6.2 Problems in an infinite medium 98

$\begin{array}{lll}6.3 & \text { Problems in the halfspace } & 104\end{array}$

7 Conclusions $\quad \mathbf{1 1 0}$

7.1 Fundamental solutions for the axisymmetric elastic fullspace and halfspace 111

7.2 The boundary element method for axisymmetric elasticity 111

7.3 The simplied-hybrid boundary element method for axisymmetric elasticity

7.4 Numerical integration 
7.5 Suggestion for future studies

8 References

A Integrals of Lipschitz-Hankel type involving products of Bessel functions

B Numerical integration

126

B.1 Regular integral

126

B.2 Weakly singular integral of logarithmic terms

126

B.3 Cauchy principal value of the singular integral of order $1 / \rho$

130 


\section{List of Figures}

Figure 2.1 - Ring loads: (a) in the radial direction; (b) in the tangential direction; (c) in the axial direction.

Figure 2.2 - Ring loads in a fullspace: (a) in the radial direction; (b) in the axial direction.

Figure 2.3 - Ring loads in a halfspace: (a) in the radial direction; (b) in the axial direction.

Figure 3.1 - Meridian plane of an elastic axisymmetric body submitted to body forces, traction forces and prescribed displacements

Figure 3.2 - Axisymmetric body submitted to: a) radial ring load; b) axial ring load.

Figure 3.3 - Integration paths of constants $c_{m n}^{\mathrm{f}}$ for (a) $\xi>0$ and (b) $\xi=0 . \quad 38$

Figure 3.4 - Local coordinate system at point $\mathrm{P}\left(\xi, z^{\prime}\right)$

Figure 3.5 - Axisymmetric halfspace submitted to: a) radial ring load; b) axial ring load.

Figure 4.1 - Meridian plane of an elastic axisymmetric body submitted to body forces, traction forces and prescribed displacements 48

Figure 4.2 - Meridian planes of an elastic axisymmetric: a) convex volume; b) non-convex volume with simply-connected surface; c) non-convex volume with multiply-connected surface; d) non-convex volume with disconnected surfaces; e) convex volume with a horizontal plane of symmetry.

Figure 5.1 - Case 1:P( $\left.\xi, z^{\prime}\right) \in \Gamma$ and $\mathrm{P}\left(\xi, z^{\prime}\right) \notin \Gamma_{t}$ for: (a) $\xi \neq 0$; (b) $\xi=0 . \quad 72$

Figure 5.2 - Case $1: \mathrm{P}\left(\xi, z^{\prime}\right) \notin \Gamma$ and $\mathrm{P}\left(\xi, z^{\prime}\right) \notin \Gamma_{t}$ for: (a) $\xi \neq 0$; (b) $\xi=0 . \quad 73$

Figure 5.3 - Case 2: $\mathrm{P}\left(\xi, z^{\prime}\right) \notin \Gamma_{t}$ and $\xi \neq 0$ for: (a) $[\rho(\eta)]_{\eta=-1}=0$; (b) $[\rho(\eta)]_{\eta=1}=0$.

Figure 5.4 - Case 3: $\mathrm{P}\left(\xi, z^{\prime}\right) \in \Gamma_{t}$ and $\xi=0$ for: (a) $[\rho(\eta)]_{\eta=-1}=0$; (b) $[\rho(\eta)]_{\eta=1}=0$.

Figure 5.5 - Case 1: $\mathrm{P}\left(\xi, z^{\prime}\right) \in \Gamma$ and $\mathrm{P}\left(\xi, z^{\prime}\right) \notin \Gamma_{t}$ for: (a) $\mathrm{P}\left(\xi, z^{\prime}\right) \in \Gamma_{i}$ and $\mathrm{Q}(r, z) \in \Gamma_{s} ;(\mathrm{b}) \mathrm{P}\left(\xi, z^{\prime}\right) \in \Gamma_{s}$ and $\mathrm{Q}(r, z) \in \Gamma_{i}$.

Figure 5.6 - Case 2: $\mathrm{P}\left(\xi, z^{\prime}\right) \in \Gamma_{i}$ and $\mathrm{P}\left(\xi, z^{\prime}\right) \in \Gamma_{t}$ for: (a) $\xi \neq 0$ and $[\rho(\eta)]_{\eta=-1}=0$; (b) $\xi \neq 0$ and $[\rho(\eta)]_{\eta=1}=0$; (c) $\xi=0$ and $[\rho(\eta)]_{\eta=-1}=0 ;$ (d) $\xi=0$ and $[\rho(\eta)]_{\eta=1}=0$.

Figure 5.7 - Case 3: $\mathrm{P}\left(\xi, z^{\prime}\right) \in \Gamma_{s}, \mathrm{P}\left(\xi, z^{\prime}\right) \in \Gamma_{t}$ and $\xi \neq 0$ for: (a) $[\rho(\eta)]_{\eta=-1}$; (b) $[\rho(\eta)]_{\eta=1}$. 
Figure 5.8 - Caso 4: $\mathrm{P}\left(\xi, z^{\prime}\right) \in \Gamma_{s}, \mathrm{P}\left(\xi, z^{\prime}\right) \notin \Gamma_{t}, \xi=0$ and $[\rho(\eta)]_{\eta=1}$.

Figure 6.1 - Boundary element model of a disc subjected to axial compression

Figure 6.2 - Basis V along the boundary ABCD 84

Figure 6.3 - Displacements along the boundary ABCD 84

Figure 6.4 - Displacements and stresses along the segment A'B' 85

Figure 6.5 - Boundary element model for a disc submitted to radial tensile traction $\quad 86$

Figure 6.6 - Displacements along the boundary ABCD 87

Figure 6.7 - Displacements and stresses along the segment A'B' 87

Figure 6.8 - Boundary element model of a hollow disc subjected to radial tensile traction 88

Figure 6.9 - Basis V along the boundary ABCD 89

Figure 6.10 - Displacements along the boundary ABCD 90

Figure 6.11 - Displacements and stresses along the segment A'B' 90

Figure 6.12 - Boundary element model of an irregularly shaped, simplyconnected domain subjected to a stress field 92

Figure 6.13 - Basis V along the boundary ABCDEF 93

Figure 6.14 - Displacements along the boundary ABCDEF 93

Figure 6.15 - Displacements and stresses along the segments $A^{\prime} B^{\prime}$ and C'D' 94

Figure 6.16 - Boundary element model of an irregularly shaped, hollow multiply-connected domain subjected to a stress field 95

Figure 6.17 - Basis V along the boundary ABCDEFA 96

Figure 6.18 - Displacements along the boundary ABCDEFA 96

Figure 6.19 - Displacements and stresses along the segments A'B' and C'D' 97

Figure 6.20 - Boundary element model of an irregularly shaped, simplyconnected cavity subjected to a stress field

Figure 6.21 - Displacements along the boundary ABCDEF

Figure 6.22 - Displacements and stresses along the segments $A^{\prime} B^{\prime}$ and C'D'

Figure 6.23 - Boundary element model of an irregularly-shaped multiplyconnected cavity subjected to a stress field

Figure 6.24 - Displacements along the boundary ABCDEFA

Figure 6.25 - Displacements and stresses along the segments $A^{\prime} B^{\prime}$ and C'D' 
Figure 6.26 - Boundary element model of a halfspace subjected to uniform pressure on a circular surface

Figure 6.27 - Displacements and stresses along the boundary $A B$ and along the segments A'B' and C'D

Figure 6.28 - Boundary element model of an irregularly shaped, simplyconnected cavity subjected to a stress field

Figure 6.29 - Displacements and stresses along the segments A'B' and C'D'

Figure 6.30 - Displacements along the boundary ABCDEF 


\section{List of Tables}

Table 6.1 - Global errors of the results found to a disc subjected to axial compression

Table 6.2 - Global errors of the results found for a disc subjected to radial tensile traction

Table 6.3 - Global errors of the results found to a hollow disc subjected to radial tensile traction

Table 6.4 - Global errors of the results found for an irregularly shaped, simply-connected domain subjected to a stress field

Table 6.5 - Global errors of the results found for an irregularly shaped, hollow multiply-connected domain subjected to a stress field 98

Table 6.6 - Global errors of the results found for an irregular simplyconnected cavity subjected to a stress field

Table 6.7 - Global errors of the results found for an irregularly-shaped, multiply-connected cavity subjected to a stress field

Table 6.8 - Global errors of the results found for a halfspace subjected to compressive load along a circular surface

Table 6.9 - Global errors of the results found for an irregularly shaped, simply-connected cavity subjected to a stress field 